\title{
Atentado em looping: uma palavra que aciona uma imagem
}

\section{Looping attacks: when a word activates an image}

\section{Ana Paula da Rosa}

Jornalista, doutora em Ciências da Comunicação pela Unisinos, mestre em Comunicação e Linguagens pela Universidade Tuiuti do Paraná. Atualmente é docente no PPG em Ciências da Comunicação da Unisinos na linha de pesquisa Midiatização e Processos Sociais onde se dedica a investigar a circulação das imagens. É vice- líder do Grupo de Pesquisa Epistecom na mesma instituição.

<anarosa208@yahoo.com.br>

\section{RESUMO}

Este artigo parte da palavra atentado para tratar das imagens simbólicas construídas pela midiatização. Com os recentes acontecimentos na França envolvendo o jornal Charlie Hebdo e com a divulgação de vídeos pelo grupo Estado Islâmico, questiona-se qual o significado que a palavra atentado convoca? Adota-se a premissa de que o imaginário coletivo é acionado por fenômenos midiáticos toda vez que um atentado ocorre pelo mundo. Então, é possível dizer que há uma figura recorrente, partilhada socialmente, no que se refere à cristalização da imagem da palavra atentado? Assim, este artigo se organiza em três etapas: a) as noções conceituais; b) o contexto midiático de aparecimento/reaparecimento de imagens e c) a articulação dos atentados com a ideia de imagem totêmica pela circulação. A hipótese de base é de que a imagem do 11 de setembro é a figura aderente, convocada seja pelo jornalismo ou por atores sociais de modo a manter uma ligação com o imaginário coletivo.

Palavras-chave: Imagens. Midiatização. Imaginário. Atentados.

\begin{abstract}
This article begins with the word attack in order to deal with symbolic images that are constructed by the media coverage. With the recent events in France involving the newspaper Charlie Hebdo and the dissemination of videos made by the Islamic State, it is asked which is the meaning that the word attack summons? The premise is that the collective imaginary is activated by media phenomena whenever an attack occurs worldwide. So, it is possible to say that there is a recurring figure, socially shared, with regard to the crystallization of the image of the word attack? Thus, this article is organized in three stages: a) the conceptual notions; b) the media context of images appearance/reappearance, and c) the articulation of the attacks with the idea of a totemic image by circulation. The base hypothesis is that the image of September 11, 2001 is the adherent figure, called either by journalism or by social actors to maintain the connection with the collective imaginary.
\end{abstract}

Keywords: Image 1. Mediatization 2. Imaginary 3. Attacks 4.

\section{Introdução}

Atentado, palavra forte, que indica por si só o fato de cometer algum delito contra o Estado ou uma autoridade, no entanto, um atentado pode se referir a uma nação, à liberdade de imprensa e expressão, à vida humana em si, mas ganha especialmente força quando se trata de um atentado simbólico. Neste sentido, a palavra convoca mais do que um significado latente, traz consigo imagens. É 
destas imagens que este artigo visa tratar, as totêmicas, invisíveis aos olhos em uma primeira instância, mas convocadas pelo imaginário coletivo e social em uma segunda, movidas pelos fenômenos midiáticos. Faz-se importante pensar, assim, o tensionamento entre imagem/imaginário e midiatização. Que imagens midiáticas são essas que nos cercam e o que elas produzem socialmente? É possível dizer que há uma figura recorrente, partilhada socialmente, no que se refere à cristalização da imagem da palavra atentado? O ponto de partida? Duas datas que se unem pela convocação de modos diversos de atentados: janeiro de 2015/ Charlie Hebdo e agosto de 2014/ decapitação de jornalistas pelo Estado Islâmico.

Em busca de tais respostas este artigo se organiza em três etapas: a) as noções conceituais de imagem, imaginário, símbolo e midiatização; b) o contexto midiático de aparecimento/reaparecimento de imagens e c) a articulação dos atentados com a ideia de imagem totêmica pela circulação.

\section{A imaterialidade da materialidade}

Considerando-se que a imagem é essa palavra tão apropriada, mas que nem sempre é entendida para além da sua característica evidente de representação de um referente, compreende-se a imagem como "uma representação visual em uma superfície bidimensional geralmente emoldurada" (Santaella; Nöth, 1997, p.38), como também uma imagem mental, que talvez nunca irá se cristalizar diante dos olhos, uma imagem imaterial.

Assim, Durand (1997) ressalta que a imagem se localiza entre a consciência e o objeto, gerando uma consciência imaginante, que é uma não-coisa, termo que Flusser emprega para referir-se às imagens, pois elas não são o objeto que mostram, são uma não-coisa, informações que formam coisas. Afinal, Wulf (2000) aborda o apropriar-se das imagens.

Fantasia, imaginação e capacidade imaginativa são três definições da capacidade humana de assimilar imagens de fora para dentro, portanto de transformar o mundo exterior em mundo interior, assim como a capacidade de criar, manter e transformar mundos imagéticos interiores, de origem e significados variados (Wulf, 2000, p. 03).

Já Gilbert Durand, citado por Cemin (1998), entende o imaginário como "o conjunto das imagens e das relações de imagens que constituem o capital do homo sapiens". Isto é, as imagens são coletadas pelos homens e vão constituindo conjuntos em torno de núcleos organizadores como os arquétipos, os quais 
revelam nas imagens materiais produzidas pelos homens. O mesmo se dá no sentido inverso, isto é, os conjuntos de imagens imateriais são revelados pelas imagens materiais, que é o que interessa em especial neste trabalho a partir dos casos empíricos.

O repertório iconográfico individual é formado por uma certa fusão entre o vivido e o não vivido, o que para Belting (1994) é resultado de uma soma de imagens "exógenas", isto é, imagens que transitam pelo exterior em suportes, que se somam e formam as imagens "endógenas", ou seja, imagens que pertencem ao universo interior, mas que são trazidas à consciência. Para Contrera e Baitello (2000) ocorre, no cenário contemporâneo, uma circulação muito grande de imagens exteriores, que estaria gerando uma crise do imaginário, uma vez que se perdeu a função que Calvino (1998) descrevia como a de "ver de olhos fechados".

Há uma exacerbação das imagens exógenas, já que quanto mais aumenta o seu fluxo, mais somos solicitados (e vemos nossa atenção nisso concentrada) a um contínuo movimento de exteriorização. $\mathrm{Na}$ mesma proporção dedica-se tanto menos atenção às imagens endógenas. Estas, é claro, não se extinguem, mas tomam-se cada vez mais inacessíveis, relegadas a um segundo e terceiro planos. Ao invés de cumprirem o papel de alimentar o âmbito externo, passam a espelhá-lo indiscriminada e acriticamente. O resultado é que o homem dos séculos XX e XXI se vê continuamente solicitado a responder às imagens do mundo, mas não pode organizá-las no seu próprio mundo interior, caótico e subnutrido de vínculos internos, perdendo o contato com suas próprias histórias. Assim, o homem contemporâneo está cada vez mais saturado de imagens exógenas e subnutrido de imagens endógenas. (Contrera; Baitello: 2006, p.07).

Neste sentido, o fotojornalismo, e em especial as agências de imagens, tem contribuído para a produção massiva de imagens exógenas. Produção esta que vem, ano após ano, deixando de estar limitada ao fazer do jornalista, uma vez que o aparelho (Flusser, 2002) está cada vez mais popularizado e os "programas" do aparato, mais acessíveis, principalmente quando se pensa nos smartphones. Isto gerou a possibilidade do cidadão comum ser um produtor de conteúdo visual, o que foi visto no 11 de setembro e no caso recente do Charlie Hebdo, em especial das repercussões.

Contudo, não é o simples fato da ampliação da produção das imagens que preocupa, ao contrário poderia ser um caminho para a ampliação da reflexão, mas ocorre um espelhamento indiscriminado e acrítico das mesmas imagens exógenas, como bem destacam Contrera e Baitello (2006), em 
múltiplos dispositivos midiáticos considerando aqui a manutenção de um papel de destaque da mídia tradicional na chancela das imagens a circular, o que será abordado mais à frente. Destaca-se, porém, que os olhos midiáticos não conseguem abarcar a gama de diversidades imagéticas que podem ser produzidas.

Toda imagem por si só, já diria Nöth $(2014$, p. 25$)$ é o resultado de uma exclusão, não apenas do instante de sua produção, mas também “há exclusões de objetos visuais devidas às limitações midiáticas de representação visual e as restrições da percepção humana". As primeiras dizem respeito ao espaço físico, bordas, tamanho, tempo, as segundas ao próprio ato de ver. Há também as exclusões que não estão no objeto representacional em si, isto é, quais coisas serão transformadas em imagens e quais nunca virão a ser de fato pertencentes a este universo, sendo excluídas antes mesmo de criadas.

Mesmo diante da compreensão de que a imagem é resultado de interações em diversos níveis, observa-se que o espelhamento das imagens exógenas é cada dia mais frequente, seja nas produções de fotografias, seja na recriação de imagens tomando como base outras imagens. Dito de outro modo, as imagens, principalmente as fotográficas, aderem-se aos fatos midiáticos, fundindo-se a eles, sendo necessário produzir mais imagens.

\section{Imagens simbólicas e sua força de fixação}

O símbolo, para Peirce (2003, p. 73), “é um representámen cujo caráter representativo consiste exatamente em ser uma regra que determinará seu interpretante". Ainda para Peirce (2003), "um símbolo, uma vez existindo espalhase entre as pessoas. No uso e na prática seu significado cresce". Isto quer dizer que aquilo que passa a circular nos meios é a força simbólica. Assim, a fotografia como testemunha do atentado no jornal Charlie Hebdo nasce da força indicial, se desprende, no entanto, pela sua exploração midiática em diversos dispositivos, passa a adquirir uma força simbólica que rompe a relação entre a fotografia indicial com o símbolo que circula, sem, por outro lado, eliminar a característica indicial. O mesmo movimento pode-se dizer do vídeo da decapitação do jornalista americano pelo Estado Islâmico. Há uma imagem indicial que se desprende, no entanto, por sua replicação, passa a adquirir uma força simbólica ou a convocar imagens simbólicas, já pertencentes ao imaginário coletivo.

Para Cassirer (1994), a chave da natureza humana é o símbolo, sendo este o traço identitário dos homo sapiens, pois esta seria a única espécie capaz de agir não apenas como um "efetuador" ou "receptor", mas com base em um "sistema simbólico". Tal sistema, conforme o autor, permite uma vivência em uma 
realidade mais ampla. "A realidade física parece recuar em proporção ao avanço da atividade simbólica do homem. Em vez de lidar com as próprias coisas o homem está, de certo modo, conversando constantemente consigo mesmo".

Joron (2006) lembra que o símbolo serve de liame entre uma coisa e suas possíveis significações, pois "permite explicar coisas ou eventos que não somos dados a perceber diretamente". Castoriadis apud Joron (2006, p 303) destaca que a sociedade recolhe material simbólico nos sistemas culturais, sejam eles do presente ou do passado, de modo que a construção do simbolismo não é totalmente livre, pois precisa levar em consideração o que já existe ou existiu.

Desta maneira, quando uma fotografia se torna um símbolo de um acontecimento, maior é o seu valor de circulação em dispositivos de instituições midiáticas e também em dispositivos midiáticos de atores individuais, ampliando seu poder de pregnância, de transcrição (ainda que aproximado) do real. Para Baitello Júnior (1999, p.109-110), os símbolos só podem se manter quando são reiterados e repetidos. "Os símbolos carecem do apoio e da confirmação, eles precisam ser reiterados no coletivo para que possam ter sua credibilidade legitimada e mantida. Sem a legitimação da sociedade eles retornam ao universo da fantasia individual".

Percebe-se, então, que a problemática do contrato social é central na análise crítica da mídia. Falar em simbólico e, principalmente, na criação de símbolos pela e para a mídia, remete ao contrato social, pois um símbolo só se efetiva mediante a replicação e legitimação da sociedade. Bourdieu (1998, p.7) destaca que o poder simbólico é "esse poder invisível, o qual só pode ser exercido com a cumplicidade daqueles que não querem saber que the estão sujeitos ou mesmo que o exercem". Portanto, o poder simbólico nada mais é do que um poder de construção de realidades, sendo que "os símbolos são os instrumentos por excelência da integração social". É perceptível, por exemplo, no 11 de setembro que imagens são eleitas para se tornarem símbolos não apenas porque são meios para representar um acontecimento, mas porque se configuram no próprio acontecimento, caso das torres gêmeas em chamas sendo atingidas pelo segundo avião. Tal ângulo de tomada constitui-se numa das imagens mais vistas e partilhadas de todos os tempos.

\section{Midiatização das imagens: potencial de inscrição na circulação}

De modo geral, a palavra midiatização tem sido empregada para definir a relação entre processos sociais e comunicacionais que resultam na produção de sentidos, também para discutir a inserção e dependência cada vez maior da tecnologia no dia-a-dia. Fausto Neto (2008) afirma que a constituição da 
sociedade se alterou em função dos novos protocolos técnicos que passaram a organizar a vida social.

Neste sentido, Gomes (2013,p. 136) vai além ao afirmar que

assumindo-se a midiatização como um novo modo de ser no mundo, tende-se a superar a mediação como categoria para se pensar os meios hoje, mesmo sendo essa mais do que um terceiro elemento que faz a ligação entre a realidade e o indivíduo via mídia. Esse conceito contempla a forma como o receptor se relaciona com a mídia e o modo como ele justifica e tematiza essa mesma relação. Por isso estrutura-se como um processo social mais complexo que traz no seu bojo os mecanismos de produção de sentido social.

As mídias se inserem no cotidiano, se relacionam diretamente com o funcionamento da cultura e da sociedade e, por consequência, se imbricam nas instituições, assim a midiatização não diz respeito somente aos meios ou às maneiras de mediação, mas essencialmente aos processos de comunicação que passam a levar em conta as dinâmicas tecno-discursivas e as lógicas das mídias, afetando âmbitos diversos. Hjavard (2014,p.24) explica que

a midiatização diz respeito às transformações estruturais de longa
duração na relação entre a mídia e outras esferas sociais. Em contraste
à mediação, que lida com o uso da mídia para práticas comunicativas
especíicas em interação situada, a midiatização preocupa-se com os
padrões em transformação de interações sociais e relações entre os
vários atores sociais, incluindo os indivíduos e as organizações. Desta
perspectiva, a midiatização envolve a institucionalização de novos
padrões de interações e relações sociais entre os atores, incluindo a
institucionalização de novos padrões de comunicação mediada.

Mais que isso, envolve um processo de reciprocidade entre mídia, cultura e sociedade, ou nos termos de Ferreira (2009), entre dispositivos, processos sociais e comunicacionais. A midiatização das imagens, aqui defendida, é um processo que envolve, portanto, a inscrição de imagens em dispositivos midiáticos, seja de instituições midiáticas jornalísticas seja de atores sociais individuais, que partilham a produção de sentidos sobre estas imagens. Tratase, essencialmente, de circulação, isto é, de fluxos entre produção e recepção, flexibilizando as bordas destes termos. No entanto, a circulação destas fotografias ou vídeos, segundo Rosa (2012), gera uma atribuição de valor que é perceptível na distribuição destas imagens em novos fluxos e circuitos (Braga, 2012).

Considera-se importante compreender que o termo circulação é entendido hoje, e já o era para o próprio Verón (2004), como uma complexificação 
e não mais como um intervalo ou defasagem entre gramáticas de produção e de reconhecimento. A circulação surge onde há troca, isto é, reconhecimento de um valor, onde produção e recepção partilham significantes. Para Fausto Neto (2013, p. 55) a circulação desponta como um território de "embates de várias ordens, produzidos por campos e atores sociais", uns que se apropriam de processos tecno-enunciativos-midiáticos e outros que visam o acesso ao âmbito da circulação buscando visibilidade, espaço, mobilização social.

Enfim, trata-se, segundo Fausto Neto (2013, p. 57), de um conjunto de estratégias realizadas, inclusive pelo próprio campo midiático, que "aponta a força da dinâmica da circulação como zona que afeta as estruturas dos campos sociais e as relações entre eles". Isto quer dizer que a circulação afeta o discurso jornalístico, assim como o discurso jornalístico, aqui em especial o imagético, afeta a atuação dos demais campos, implicando na produção visual sobre os acontecimentos. Evidencia-se uma orquestração visual partilhada, via circulação, mas que, como já referido anteriormente, é chancelada pelas instituições midiáticas tradicionais. Exemplo disto é a fotografia da redação do jornal Charlie Hedbo, logo após a invasão terrorista, é produzida por um fotógrafo do Jornal Le Monde e reproduzida na web, no jornal impresso francês, na capa de inúmeros periódicos, como em quadro parado em reportagens de televisão. A imagem foi replicada também em perfis de facebook, curtida, comentada, reinserida, o que demonstra um potencial de circulação e uma amplitude de distribuição. O que chama tanto a atenção nesta imagem? A curiosidade? A presença ausente da morte? Ou o simples furo jornalístico de ter sido o primeiro a ter estado lá, o que suscita que todos se tornem, em qualquer parte do mundo, uma testemunha da cena? Também sendo transformados em alvo da ameaça "Vocês vão pagar por ter insultado o profeta" (FIG. 01). 


\section{Société}

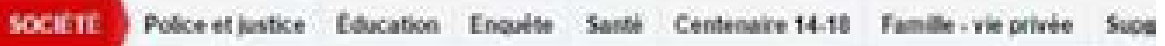

\section{Attentat à "Charlie Hebdo ": "Vous allez payer car vous avez insulté le Prophète "}
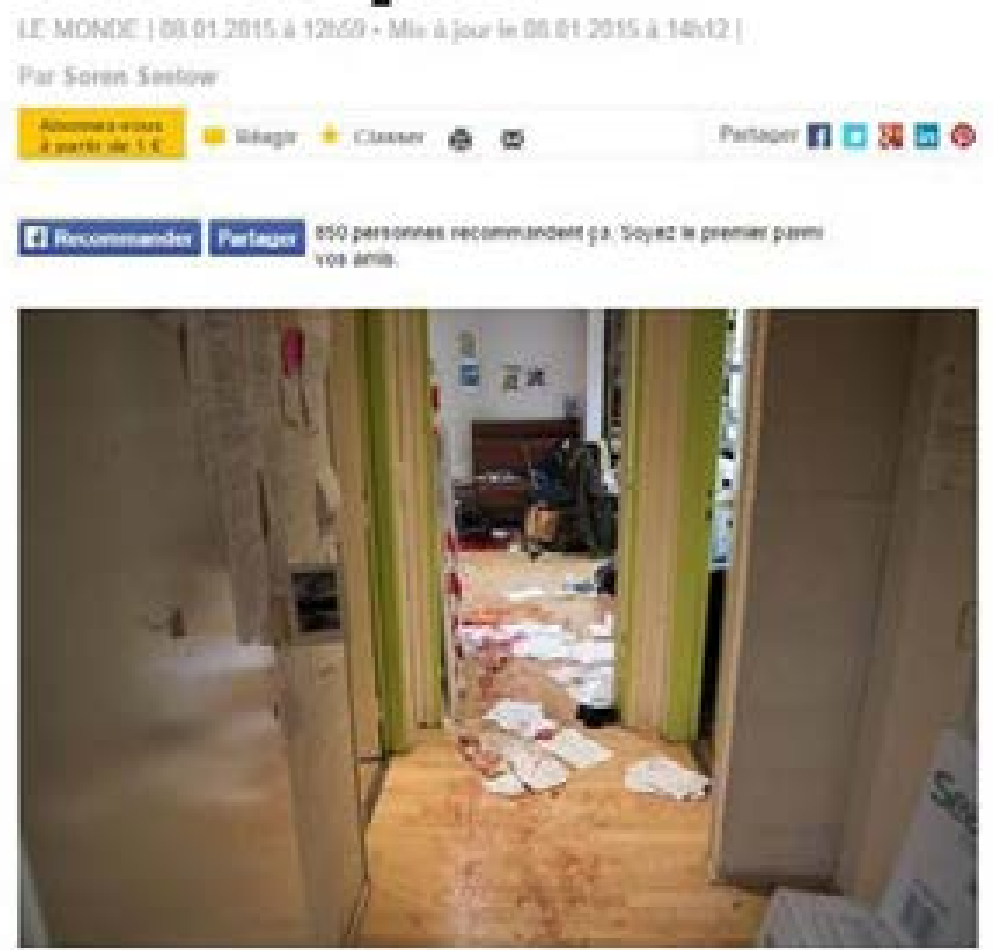

- Figura 01-Imagem da redação publicada pelo Le Monde

(fonte: <http://extra.globo.com/incoming/14997415-ed3-506/w448/Le-Monde-2.png.jpg> )

\section{Imagens dos atentados: convocação do imaginário}

A partir da tessitura conceitual sobre imagem, imaginário, símbolo e midiatização torna-se possível identificar nos materiais empíricos como a palavra atentado foi ressignificada, preservando-se, aqui, os modos diversos de atentados, bem como as autorias dos grupos terroristas que não são confirmadas. $O$ que interessa investigar neste artigo não é a abordagem política dos atentados, mas como midiaticamente suas versões estão ou foram sendo construídas e postas em circulação. Foram escolhidos dois casos distintos: janeiro de 2015/ Charlie Hebdo e agosto de 2014/decapitação de jornalistas pelo Estado Islâmico. Metodologicamente cada um foi visto de modo isolado e posteriormente articulado no conjunto das materialidades. A pergunta central é: é possível dizer que há uma figura recorrente, partilhada socialmente, no que se refere à cristalização da imagem da palavra atentado? A hipótese deste 
artigo é de que a imagem do 11 de setembro é a imagem aderente à palavra atentado, convocada sempre que possível, seja pela reportagem ou por atores sociais, mantendo uma ligação com o imaginário coletivo.

\section{Je Suis Charlie - 07 janeiro de 2015}

Janeiro de 2015, dia 07. A redação do jornal francês Charlie Hebdo, já alvo de ameaças e críticas por seu ferrenho posicionamento, é invadida por dois homens armados que rendem uma cartunista e matam seis integrantes da equipe do periódico, dentre os quais Bernard Marris, Georges Wolinski, Jean Cabu, Stéphane Charbonnier, Bernard Verlhard (Tignous) e Philippe Honoré. Outros dois policiais também são mortos e 11 pessoas ficam feridas. A França se mobiliza, pois o alvo foi não apenas um veículo de comunicação, mas a própria liberdade de imprensa e expressão. Assim, midiaticamente constrói-se uma cobertura jornalística que mostra a narrativa do que se chamou de "atentado"e seus impactos sociais. Midiaticamente, pois as redes sociais tiveram um papel crucial no sentido de mobilização para passeatas e para o movimento intitulado "Je Suis Charlie".

As instituições midiáticas jornalísticas tão logo foram informadas do acontecido trataram de promover uma cobertura minuto a minuto dos desdobramentos, seja pelas redes de TV, sites de jornais impressos e online e pela ampla repercussão em meio aos cartunistas e chargistas do mundo todo. As primeiras imagens mostravam com pouca proximidade os feridos sendo deslocados da redação, bem como o forte cerco policial. Receberam destaque as imagens da mobilização social com o Je Suis Charlie assumido tão logo o site do jornal francês passou a publicar em idiomas diferentes a frase. (FIG. 02) 


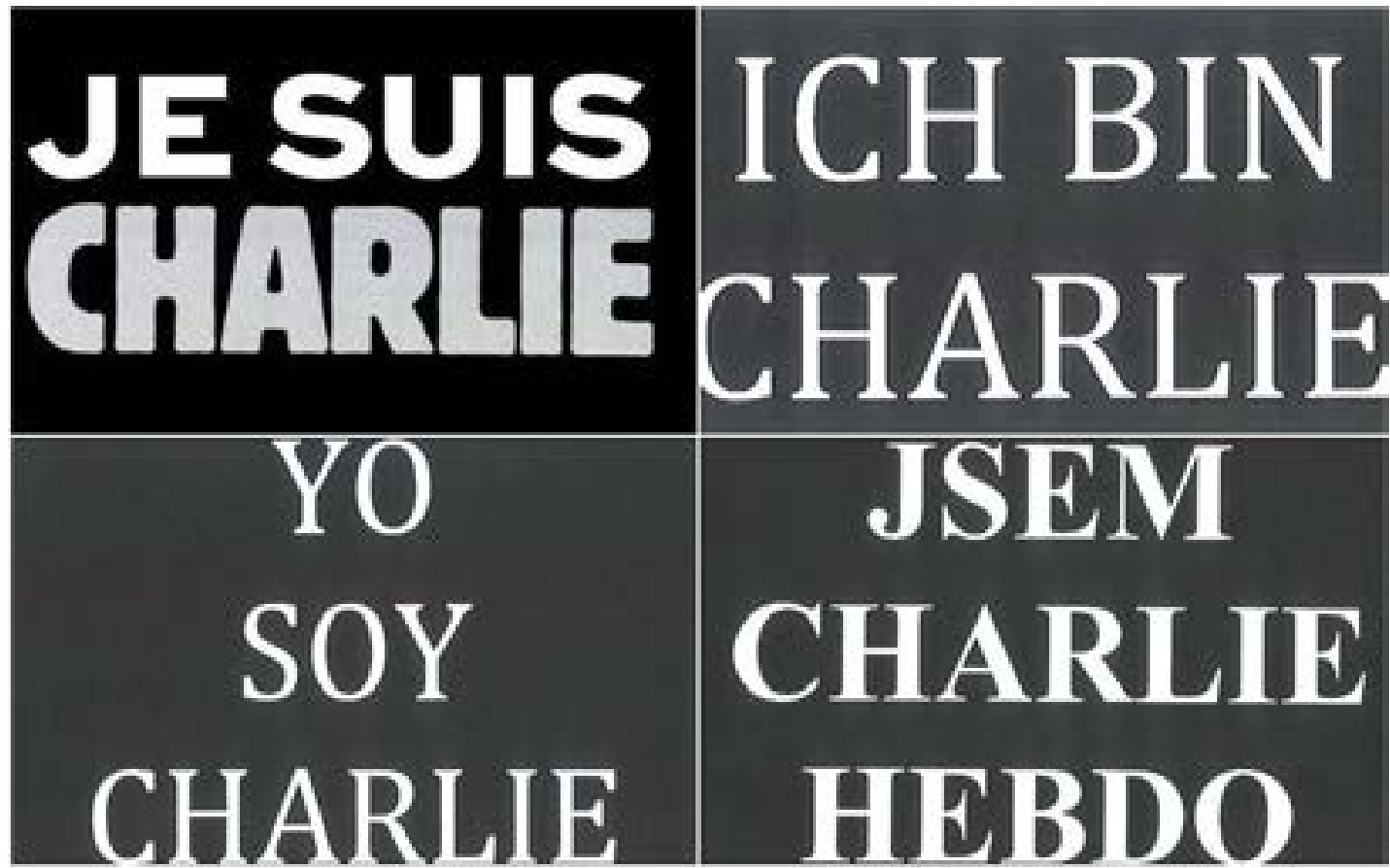

- Figura 02 - Imagem do site do jornal Charlie Hebdo horas após o ataque

(fonte < http://imgsapp2.correiobraziliense.com.br/app/noticia_127983242361/2015/01/07/465139/2 0150107162133652372i.jpg >)

No Brasil manifestações foram realizadas no Rio de Janeiro e em São Paulo, para além dos perfis das redes sociais. Embora um movimento contrário também foi registrado (Nós não somos Charlie) referindo-se ao teor das charges do periódico francês, a Rede Globo "solidarizou-se" com o Charlie Hebdo destacando entrevista no Jornal Nacional, reproduzida na íntegra pelo portal G1 < http://g1.globo.com/jornal-nacional/noticia/2015/01/e-muito-chocante-dizziraldo-sobre-atentado-jornal-frances.html > com diversos chargistas, dentre os quais se ressalta a frase de lque em que afirma: "Esse atentado chocou a todos nós, principalmente os cartunistas. E eu comparo esse atentado ao 11 de setembro. Esse é o 11 de setembro dos cartunistas. (...) jamais imaginei que um desenho pudesse provocar um ataque terrorista". No mesmo sentido, a France Press divulgou a frase de ex-editor da revista 'Charlie Hebdo saute sur Toulon', Mourad Boudjellal, responsável pela publicação em 1995, que considerou este o "11/09 da imprensa". Tal notícia foi divulgada em sites internacionais e no jornal Correio Brasiliense com destaque.

Além das afirmações referentes ao 11/09, outra retomada das torres ocorreu explicitamente pelo cartunista holandês Ruben L. Oppenheimer, que fez uma charge em que dois lápis estão prestes a serem atingidos por um avião, em alusão ao ataque contra as torres do World Trade Center, em 2001. (FIG. 03) 


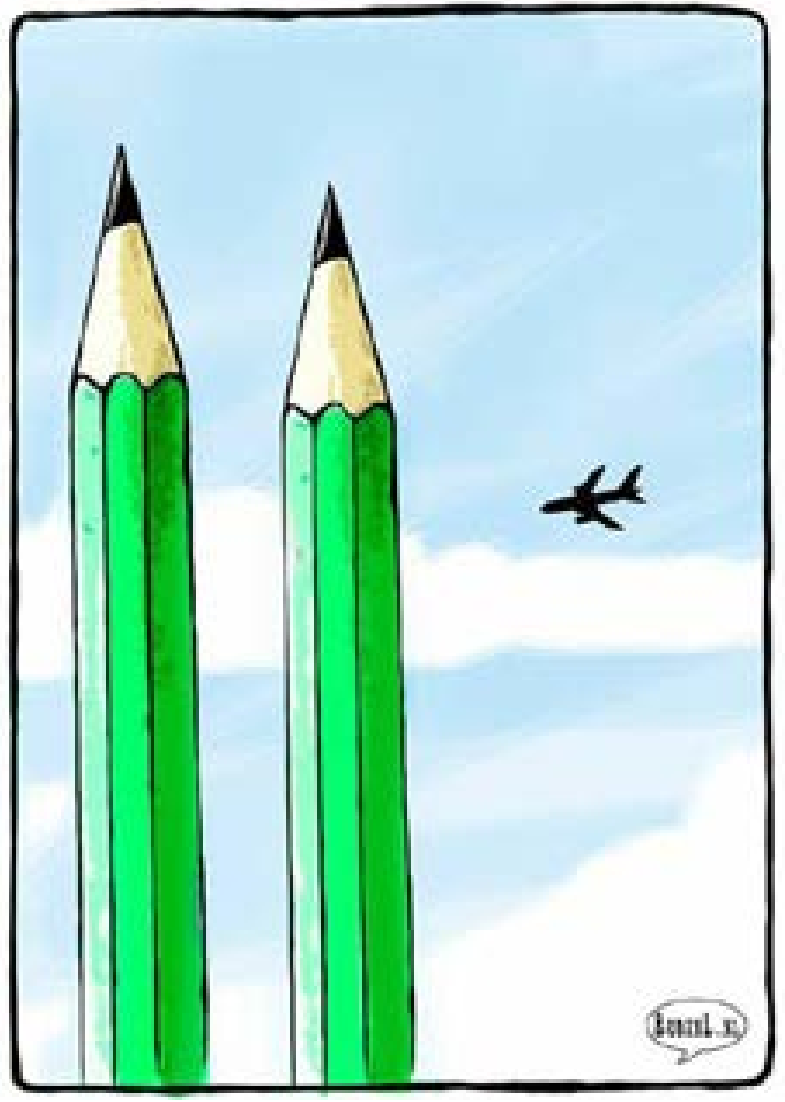

- Figura 03 - Charge holandesa homenageia jornal francês

(fonte: http://imagens0.publico.pt/imagens.aspx/895490?tp=UH\&db=IMAGENS )

Percebe-se uma tentativa midiática de atrelar o ocorrido na redação do Charlie Hebdo ao atentado às Torres Gêmeas, talvez como uma forma de autorização social e coletiva para uso da expressão "atentado". Em outro aspecto, é possível dizer que ao considerar as mortes na redação francesa um atentado terrorista a referência de atentado é imediatamente convocada, logo, adere-se à imagem do 11 de setembro. Reproduz-se esta cena mesmo quando outros atentados como Madrid e Londres tenham sido registrados e que, em sua época, convocaram o 11 de setembro. Assim, a imagem simbólica acionada, com valor para além de sua aparência não é outra senão a das torres em chamas, mesmo transcorridos 14 anos. A charge acima recria o momento do atentado ao World Trade Center, segundos antes do avião colidir, isto é, o fato ocorre novamente diante dos olhos, só que desta vez quebra não o centro da economia, mas o da criatividade. $O$ que indica a presença de uma imagem totêmica, portanto simbólica e autorreferencial, que se estende para além do fato que indicia. 
No caso do Charlie Hebdo há inicialmente um impedimento de acesso às imagens do fato. A instituição não midiática polícia cerca o local, impedindo a visualização do fato em si ou da cena de sua constituição. Como imagem deste, surgem as manifestações de Je Suis Charlie em diversos pontos da França e do mundo. Entram imagens concorrentes à do local do crime em si, outros focos de ação terrorista, repercussões visuais na web até que, para preencher o vazio imagético figurativo das mortes ou dos corpos, replica-se a imagem do 11 de setembro, em múltiplos dispositivos midiáticos. Imagem esta que traz consigo toda uma carga de outras inscrições e uma legitimação social. Significa dizer, portanto, que as demais imagens deixaram de estar acessíveis ou de importar? Não, mas foram impactadas também pela noção de atentado já experimentado antes. Um exemplo são as imagens de homenagens deixadas na calçada em frente ao local do atentado, um ato silencioso repetido por familiares das vítimas do 11 de setembro, uma lógica vista também no caso Hebdo.

\section{Estado Islâmico, feitos para vingar: 20 de agosto de 2014}

No que tange aos vídeos de decapitação de jornalistas americanos pelo Estado Islâmico, a ligação com a imagem do WTC em chamas é ainda mais imediata. Os vídeos produzidos pelo grupo são feitos especialmente para ser midiatizados, isto é, a instituição Estado Islâmico (EI) se vale de lógicas midiáticas para produzir vídeos em que registra o momento exato da execução de pessoas pensando em sua distribuição. Isso é perceptível, pois o vídeo é feito com duas câmeras, colocadas em ângulos distintos, e com uso de microfone de lapela. $O$ primeiro deles foi veiculado em 20 de agosto de 2014 e refere-se à execução do jornalista americano James Foley, 40 anos, que havia sido sequestrado pelas forças jihadistas em 2012. Vestido com uniforme laranja, o jornalista aparece ao lado de um homem, lê uma mensagem de apelo aos familiares e aos "verdadeiros culpados de sua condenação", os EUA, e em seguida é decapitado (FIG. 04). 


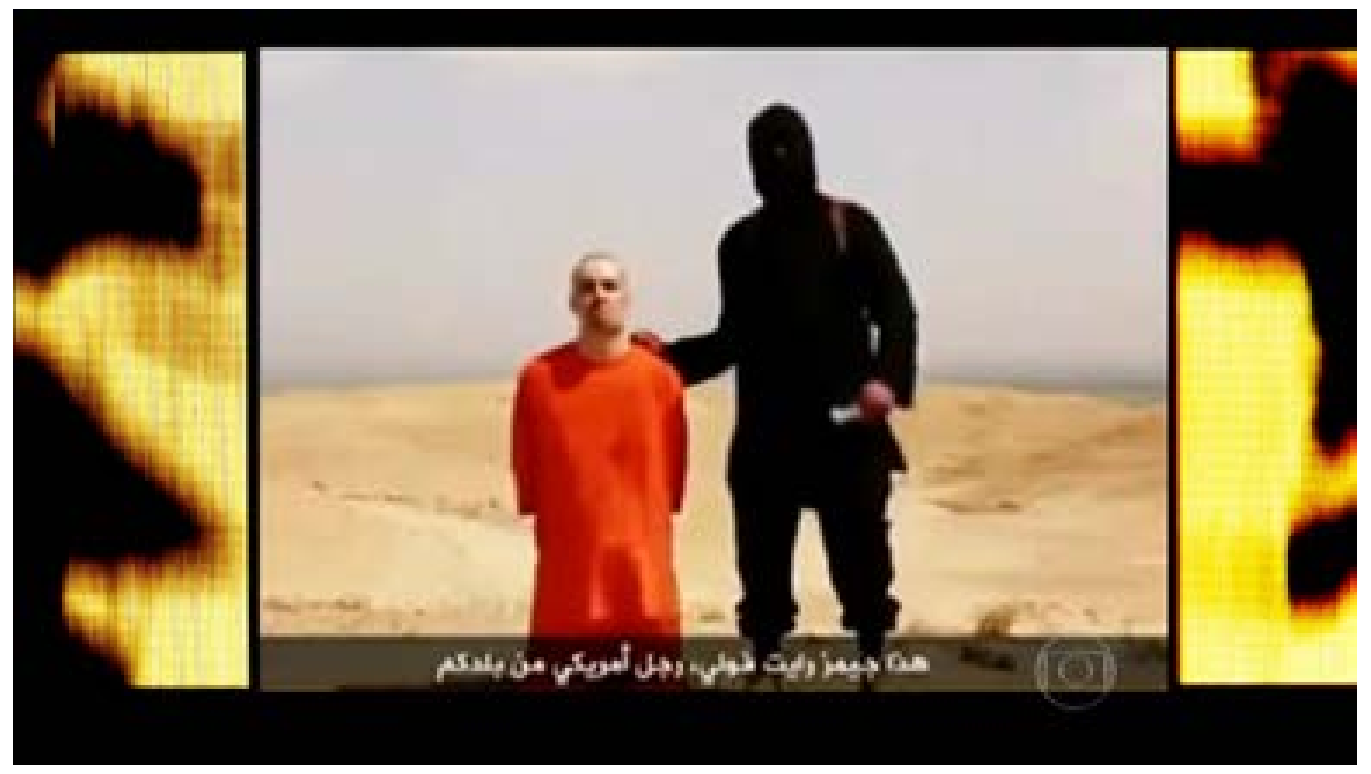

\section{Figura 04 - Frame da reportagem do Fantástico com a inserção do vídeo EI}

( fonte: <http://g1.globo.com/fantastico/noticia/2014/08/estado-islamico-conheca-o-grupo-radicalque-espalha-terror-pela-siria-e-iraque.html>)

No entanto, pelo horror da cena, a decapitação é vista na web, meio pelo qual o vídeo é distribuído e posto em circulação, mas o teor do vídeo não chega a ser exibido pelas emissoras de TV tradicionais em virtude da crueza das imagens. Jornais do mundo todo colocam quadros parados com frames minutos antes da execução, pois não é possível, pelas regras jornalísticas, expor tamanha violência. Com isso, a imagem que era para ser midiatizada é impedida em sua raiz, mas a sua existência gera curiosidade e consequentemente acessos e visualizações aos vídeos que são replicados em páginas diversas. Os veículos de comunicação tradicionais têm o vídeo como base, mas ele não é suficiente para sustentar as reportagens, assim são feitas ligações entre a decapitação do jornalista americano com os atentados terroristas e, logo, com as imagens do 11 de setembro.

Não é fenômeno simples, porque implica dizer que toda vez que o Estado Islâmico se manifesta com outras ações, sua imagem fica atrelada ao 11/09, o que pode gerar o fortalecimento da noção de ódio entre países e a criação de estereótipos em relação ao povo muçulmano, ao Islã e em especial a ideia de que são "criados para matar", com no vídeo recentemente divulgado, em janeiro de 2015, em que uma criança supostamente executa dois homens em condições semelhantes a do jornalista ocorrida em agosto de 2014.

O Fantástico da Rede Globo realizou duas reportagens sobre os grupos extremistas. Em 24 de agosto de 2014 apresentou a reportagem produzida por 
Rodrigo Alvarez com base em documentário produzido pela Revista Canadense Vice, sobre o grupo Estado Islâmico. Além das cenas do vídeo da execução do jornalista James Foley, são empregadas imagens de vídeos disponibilizados na web pelo próprio grupo com suas ações, bem como recuperadas imagens do atentado de 11 de setembro. O alerta de "vejam, eles podem fazer isso de novo" vem em tom ameaçador, pois alega o off, reproduzido no portal G1 que o El "Seriam, portanto, mais organizados, ricos e perigosos até do que a rede terrorista Al-Qaeda, que derrubou as Torres Gêmeas do World Trade Center em 11 de setembro de 2001", justificando a ligação e reiterando o símbolo (FIG.05).

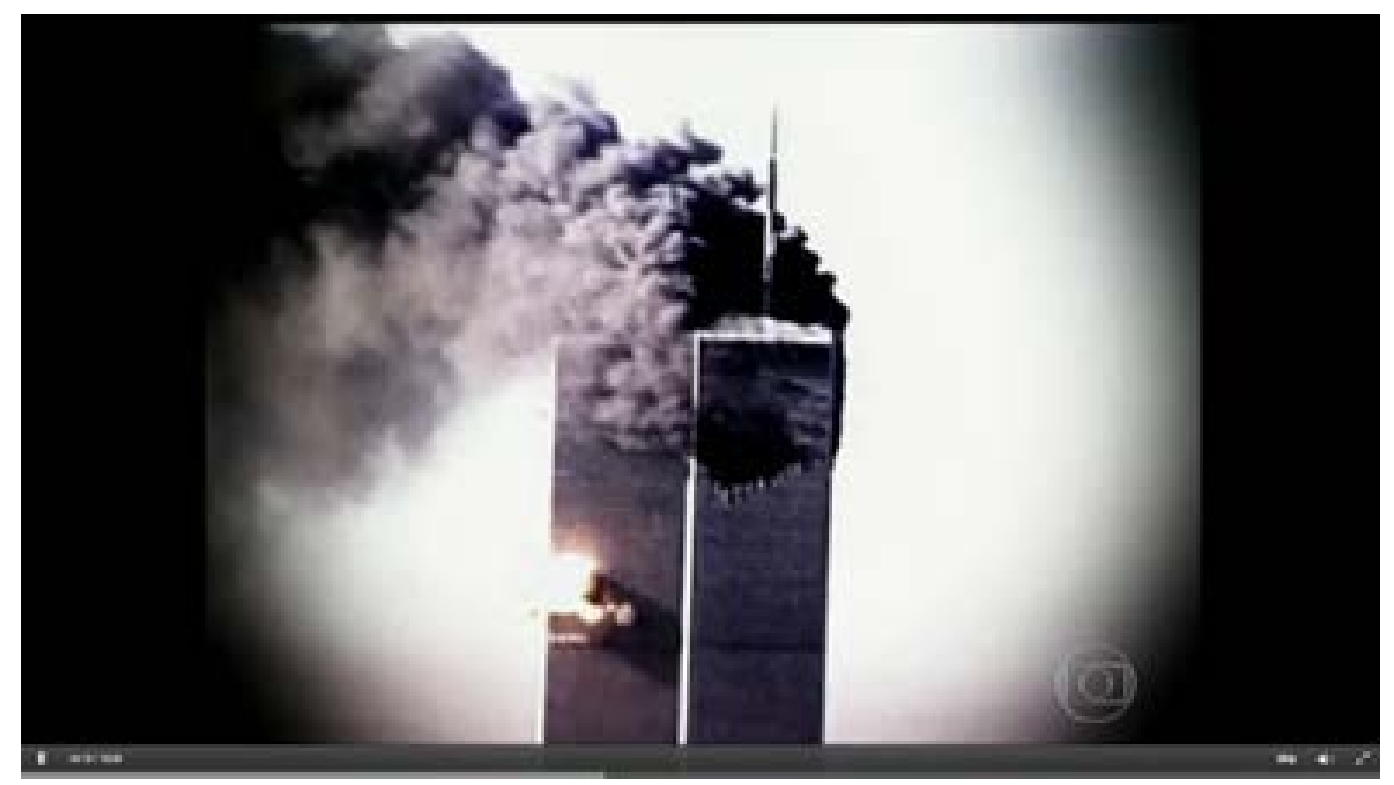

Figura 05 - Frame da reportagem do Fantástico com a inserção de cena do WTC

( fonte: < http://g1.globo.com/fantastico/noticia/2014/08/estado-islamico-conheca-o-grupo-radicalque-espalha-terror-pela-siria-e-iraque.html >)

Na edição de 18/01/2015 o Fantástico exibiu nova reportagem sobre os grupos extremistas em atuação na atualidade, recuperando imagens da reportagem já veiculada do Estado Islâmico e inserindo inéditas de grupos como Boko Haram, Al-Qaeda do lêmen entre outros. O que chama a atenção é que a reportagem especial foi produzida em virtude do atentado ao Charlie Hebdo, mas é o 11 de setembro que é convocado logo no abre da matéria. 
Nomes estranhos, com significados geralmente pretenciosos, que foram se tornando comuns e assustadores desde que o maior atentado da história, numa manhã de terça-feira em Nova York, inaugurou um novo milênio. Uma época até agora marcada pelo embate entre terroristas islâmicos e o chamado Ocidente. (< http:// g1.globo.com/fantastico/noticia/2015/01/conheca-como-agem-eo-que-querem-os-grupos-terroristas-mais-perigosos.html >)

Quanto às imagens, a reportagem traz as mesmas cenas do vídeo de 24/08/14, reforçando a criação das imagens totens pela circulação, isto é, as imagens que se fixam não são as dos grupos em si ou das ações isoladas, mas a figurativização do Ocidente pelas torres em chamas. Neste sentido, há um apagamento de outras imagens possíveis para simbolizar os atentados e o reaparecimento de uma ou de poucas imagens referentes ao World Trade Center que recriam a ambiência do terror, não mais referindo-se ao fato em si, mas à imagem cristalizada do acontecimento midiático fixado nas páginas, nos sites, nas múltiplas telas, nas retinas.

\section{Considerações finais}

Com base no exposto, o poder simbólico das imagens midiáticas se dá pela ordem do aparecimento no espaço midiático, apagamento/ocultação da indicialidade e reaparecimento a partir de lógicas próprias do campo das mídias. Isto gera um deslocamento do fato, que adere como um emblema (totem) ao acontecimento midiático, mobilizando a memória, interligando acontecimentos dissociados no tempo e no espaço. Ou seja, o que se torna acessível é apenas o símbolo construído. Deste modo, os movimentos de criação simbólica pela midiatização, centrando-se principalmente na atuação das instituições midiáticas e dos atores individuais, permitem o surgimento de imagens-totens, que ganham tamanho relevo que ultrapassam a durabilidade dos fatos, transformando-se elas mesmas em sínteses dos acontecimentos, com capacidade de permanência na memória coletiva e midiática.

Pode-se dizer que o totemismo trata da crença, a crença que liga o homem ao seu estado mais primitivo. Na verdade, a ideia de totem está ligada à concepção de uma substituição, isto é, o objeto tomado como representativo assume o lugar daquilo que representa e passa a ser adorado, sacralizado por isto. Strauss (1975, p. 13) defende que o totem é uma projeção de atitudes mentais "incompatíveis com a exigência de uma descontinuidade entre o homem e a natureza", isto é, trata-se de um elemento estritamente da ordem do interno que é exteriorizado socialmente. Durkheim (2009) afirma que a crença e 
os ritos estão diretamente ligados e são inerentes a todo sistema totêmico, pois o culto ao objeto, à coisa, deriva da crença partilhada, ao mesmo tempo em que o ritual é empregado como uma forma de justificar tal crença. Isto significa que a crença existe quando se constitui em uma regra. Neste sentido, as imagens que transitam por diversos dispositivos midiáticos, sejam jornalísticos ou não, estão inseridas em rituais diversos, mas existem para uma coletividade de indivíduos, apesar destes serem heterogêneos e difusos. No entanto, há um reconhecimento e uma crença comum que perpassam estas imagens.

Nesta ambiência dos dispositivos midiáticos, uma vez que, segundo Bourdieu (2011), a imagem é um poder estruturante de interações ao mesmo tempo em que é estruturado, questiona-se: como a imagem se constitui em poder e, principalmente, poder simbólico? A perspectiva adotada, aqui, é de que a comunicação é ritualística e baseada em múltiplas trocas. A imagem construída como crença simbólica - ou totem - só se consolida, em processos sociais, quando consegue se impor em rituais sociais de reiteração, o que se percebe no caso do 11 de setembro.

Asuposição do porquêse escalam taisimagenscomosímbolosdominantes perante outros e por que elas, de certa forma, consolidam determinadas possibilidades em termos de imaginários dos receptores e produtores, inclusive dos críticos, é de que haveria estruturas profundas que se manifestam nas processualidades midiáticas que acabam designando os atores sociais. No caso do jornal Charlie Hebdo, tanto o chargista holandês como a instituição midiática jornalística, como a Globo, por exemplo, acabam condicionando as possibilidades de reflexão e de interpretação da situação, na medida em que delimitam as possibilidades de simbolização e de outras relações. Isto é ainda mais gritante no caso dos grupos extremistas como o Estado Islâmico em que a ligação com a palavra atentado é quase instantânea com a imagem das torres em chamas, o que faz com que a palavra em si tenha seu significado como em um decalque à fotografia referida.

Portanto, trata-se de um poder que se instala e que pode ser observado nas relações e interações estratégicas e ritualísticas. Reforça-se, porém, que este poder é transcendente em relação às ações e interações, pois é, de certa forma, um símbolo de alguma estrutura profunda do social que se manifesta. $O$ totem, para Cassirer (2004), é exatamente esta estrutura profunda, manifesta por um tipo de intuição mítico-religiosa que realiza a ordenação do mundo e que gera um sentimento de pertença. Tais colocações são importantes para entender que, na criação das imagens-totens pela midiatização, há uma convocação 
do imaginário, ou seja, de imagens imateriais prévias. Se, por um lado, há um bloqueio das relações e dos símbolos possíveis, há, derivado disso, um bloqueio dos imaginários, e, por decorrência, de outras relações reais. O inverso nesse sentido, é válido, pelo bloqueio das possibilidades de objeto, há uma limitação do próprio imaginário.

Em síntese, a criação de imagens simbólicas pela midiatização implica, ao mesmo tempo, no apagamento/desaparecimento de imagens do espaço midiático e na veneração de um número cada vez mais restrito de imagens, apesar da existência e do acesso a uma multiplicidade de dispositivos e de formas de ver. Flusser (1999) utiliza a metáfora da gula para exemplificar a ideia do consumo das imagens, isto é, para ele, o trabalho da comunicação e da mídia é "devorar para criar vazios devoradores", ou seja, devorar imagens para devolver apenas uma, esta, cristalizada como um símbolo do acontecimento, que pode se ligar a múltiplos acontecimentos como no caso da expressão "atentado".

Identifica-se, assim, o fenômeno de autorreferencialidade, pois as imagens se tornam cada vez mais janelas para si próprias. Klein e Rosa (2007) já abordaram o fenômeno da circularidade das imagens midiáticas e, para os autores, as reiterações e reaparições das fotografias dos atentados terroristas são mais do que uma "circularidade no tempo nas imagens, mas a circularidade das imagens no tempo", tal situação é intensificada, hoje, nesta visada pelo que se chama de totemismo. Uma vez que não se trata apenas de uma volta cíclica, mas de uma reiteração que gera apagamentos e consolida crenças. Se antes a pergunta era quais as imagens futuras do 11 de setembro, agora talvez se tenha a resposta: sua permanência a pairar.

\section{Referências}

ARAUJO, Denize (org). Imagem (I.R.) Realidade: comunicação e cibermídia. Porto Alegre: Sulina, 2006.

BAITELLOJUNIOR, Norval.O animal que parou os relógios: ensaios sobre comunicação, cultura e mídia. São Paulo: Annablume, 1999, reimpressão 2003.

A era da iconofagia: ensaios de comunicação e cultura. São Paulo: Hacker Editores, 2005.

. A serpente, a maça e o holograma: esboços para uma Teoria da Mídia. São Paulo: Paulus, 2010.

BAITELLO JUNIOR, Norval; CONTRERA, Malena. Na selva das imagens: Algumas contribuições para uma teoria da imagem na esfera das ciências da comunicação. 
Revista Significação. Vol 33. № 25. São Paulo: Editora USP, 2006.

BRAGA, José Luiz; FERREIRA, Jairo; FAUSTO NETO, Antônio; GOMES, Pedro Gilberto. (orgs). Dez perguntas para a produção de conhecimento em comunicação. São Leopoldo: Ed. Unisinos, 2013.

BRAGA, José Luiz. Circuitos versus campos sociais. IN: JANOTTI JUNIOR, Jeder; MATTOS, Maria Angela; JACKS, Nilda (orgs) Mediação \& midiatização. Salvador: Edufba: Brasília: Compós, 2012.

BELTING, Hans. Likeness and presence:a history of the image before the era of art. Chicago, London: The University of Chicago Press, 1994.

Pour une anthropologie dês images. Paris: Gallimard, 2004

BYSTRINA, Ivan. Tópicos de Semiótica da cultura. São Paulo: CISC, 1995.

BOURDIEU, Pierre. O poder simbólico. 15ª edição. Rio de Janeiro: Bertrand Brasil, 2011.

CALVINO, Ítalo. Seis propostas para o próximo milênio: lições americanas. $2^{a}$ edição. São Paulo: Companhia das Letras, 1998.

CASSIRER, Ernst. Ensaio sobre o homem. Uma introdução a uma Filosofia da Cultura Humana. Ed Martins Fontes: São Paulo, 1994.

A filosofia das formas simbólicas. Vol II - O pensamento mítico. São Paulo: Martins Fontes, 2004

CEMIN, Arneide. Entre o cristal e a fumaça: afinal o que é imaginário? Presença Revista de Cultura e Meio Ambiente. Porto Velho, Fundação Universidade Federal de Rondônia v. 5, no 14. Dez./1998.

DURAND, GILBERT. A imaginação simbólica. São Paulo: Cultrix/Edusp, 1998.

Estruturas antropológicas do imaginário: introdução e arquetipologia. 2a edição. São Paulo: Martins Fontes, 2001.

DURKHEIM, Émile. As formas elementares da vida religiosa: o sistema totêmico na Austrália. 4ª Edição. São Paulo: Martins Fontes, 2009.

FAUSTO NETO, Antônio. A midiatização jornalística do dinheiro apreendido: das fotos furtadas à fita leitora. Disponível em www.compos.org.br/biblioteca 245pdf < Acesso em 20/07/2008>.

FERREIRA, Jairo. Midiatização: dispositivos, processos sociais e de comunicação. Revista E-Compós (Brasília), v. 10, p. 1-15, 2007.

FLUSSER, Vilém. Filosofia da caixa preta: ensaios para uma futura filosofia da 
fotografia. Rio de Janeiro: Relume Dumará, 2002.

O mundo codificado: por uma filosofia do design e da comunicação. Organizado por Rafael Cardoso. São Paulo: Cosac Naify,2007.

O universo das imagens técnicas: elogio da superficialidade. São Paulo: Annablume, 2008.

JORON, Phillipe. Alteridade simbólica e construção marginal da realidade. IN: Imagem ( I.R.) Realidade: comunicação e cibermídia. Porto Alegre: Sulina, 2006. p. 290-305.

HJAVARD, STIG. Midiatização: conceituando a mudança social e cultural. Revista Matrizes, v.8 - no 1 jan/jun. São Paulo: 2014. (p. 21 - 44). http://dx.doi. org/10.11606/issn.1982-8160.v8i1p21-44

KLEIN, Alberto; ROSA, Ana Paula. Atentado em imagens: sincronização e circularidade na mídia. Revista Grhebh, nº 08, julho, 2007.

KLEIN, Alberto. Imagens do culto e imagens da mídia. Porto Alegre: Sulina, 2006.

NÖTH, Winfried. O que as imagens excluem e como o excluído é incluído novamente. Revista Líbero. V. 17, no 33. São Paulo: Faculdade Cásper Líbero, 2014. (p. 21-30)

SANTAELLA, Lúcia. Imagens são óbvias ou astuciosas. Revista Líbero. V. 17, n 33. São Paulo: Faculdade Cásper Líbero, 2014. (p.13-18)

;NÖTH, Winfried. Imagem: cognição, semiótica, mídia. São Paulao: Iluminuras, 1997.

PEIRCE, Charles. Semiótica. São Paulo: Perspectiva, Ed. atualizada, 2003.

ROSA, Ana Paula da. Imagens-totens: a fixação de símbolos nos processos de midiatização. 2012. 360 f. Tese (Doutorado em Ciências da Comunicação) Programa de Ciências da Comunicação, Unisinos, Porto Alegre, 2012. Disponível em <http://biblioteca.asav.org.br/vinculos/000003/0000033A.pdf>

STRAUSS, Lévi. O totemismo hoje. Petrópolis: Vozes, 1975.

VERON, ELISO. Fragmentos de um tecido. São Leopoldo: Ed. Unisinos, 2004.

WULF, Christoph. Imagem e fantasia. 2000. Disponível em: <http://www.cisc.org.br/ portal/index.php/biblioteca/viewdownload/4-wulf-christoph/26-imagem-efantasia.html> Acesso em 12/12/2014. 


\section{Documentos de Acesso Exclusivo em Meio Eletrônico}

Capa do site do jornal Charlie Hebdo disponível no Correio Braziliense. Disponível em: <http://imgsapp2.correiobraziliense.com.br/app/noticia 127983242361/2015 101/07/465139/20150107162133652372i.jpg > Acesso em 12/01/2015.

Charge holandesa. Disponível em: <http://imagens0.publico.pt/imagens. aspx/895490?tp=UH\&db=IMAGENS > Acesso em 12/01/2015.

Imagem Redação Charlie Hebdo - Le Monde. Disponível em: <http://extra.globo. com/incoming/14997415-ed3-506/w448/Le-Monde-2.png.jpg > Acesso em 09/01/2015.

Reportagem Jornal Nacional com repercussões do atentado Charlie Hebdo. Disponível em: <http://g1.globo.com/jornal-nacional/noticia/2015/01/e-muito-chocantediz-ziraldo-sobre-atentado-jornal-frances.html?> Acesso em 09/01/2015.

Reportagem do Fantástico sobre Grupo Estado Islâmico. Disponível em: <http:// g1.globo.com/fantastico/noticia/2014/08/estado-islamico-conheca-o-gruporadical-que-espalha-terror-pela-siria-e-iraque.html> Acesso em 19/01/2015.

Reportagem do Fantástico sobre Grupos Extremistas. Disponível em: < http://g1.globo. com/fantastico/noticia/2015/01/conheca-como-agem-e-o-que-querem-osgrupos-terroristas-mais-perigosos.html> Acesso em 19/01/2015.

Recebido em: 07/06/2015

Aceito em: 17/06/2015

Endereço do autor:

Ana Paula Rosa < anarosa208@yahoo.com.br >

Universidade do Vale do Rio dos Sinos, Centro de Ciências da Comunicação.

Avenida Unisinos - São João Batista

93022000 - São Leopoldo, RS - Brasil

Telefone: (51) 35911122 - Ramal: 1391 